PRINT ISSN 1119-8362

Electronic ISSN 1119-8362
Full-text Available Online at https://www.ajol.info/index.php/jasem

http://ww.bioline.org.br/ja
J. Appl. Sci. Environ. Manage.

Vol. 25 (4) 493-496 April 2021

\title{
Chromosomes Behavior at Meiosis in Chlorophytum stenopetalum Bak at Pachytene, Diakinesis and Diplotene
}

\section{OMOKANYE BABATUNDE SIKIRU}

\author{
National Open University of Nigeria, Offa Community Study Center, Offa, Kwara State, Nigeria
}

Email: omokanyebabatundesikiru@yahoo.com

\begin{abstract}
Meiotic prophase is classically subdivided into five stages: leptotene, zygotene, pachytene, diplotene, and diakinesis. The objective of this paper is to evaluate the behaviours of Chromosomes in Chlorophytum stenopetalum Bak.at pachytene /diakinesis and metaphase. The flower buds at right age were harvested, fixed in Cornoy's solution (3 part of absolute alcohol and 1 part of acetic alcohol) and preserved in a refrigerator at $-4^{\circ} \mathrm{C}$ for at least thirty minutes. The flower buds were then hydrolyzed in $10 \% \mathrm{HCl}$ for 3-5 minutes. Prepared slides were viewed using an Armscope microscope equipped with digital automatic camera. At diakinesis seven bivalents (7 II) were predominantly observed (74.2\%). Chromosomal stickiness is quite evidence. In addition, cross configuration and its resultant, ring formation at metaphase indicate the presence of translocation heterozgosity in the chromosomes of the species investigated. These abnormalities are likely to affect microsporogenesis and pollen viability.
\end{abstract}

\section{DOI: DOI: https://dx.doi.org/10.4314/jasem.v25i4.1}

Copyright: Copyright $\left({ }_{0} 2021\right.$ Omokanye. This is an open access article distributed under the Creative Commons Attribution License (CCL), which permits unrestricted use, distribution, and reproduction in any medium, provided the original work is properly cited.

Dates: Received: 10 January 2021; Revised: 12 February 2021; Accepted: 09 March 2021

Keywords: Translocation heterozygosity, Pachytene, Diakinesis, Chlorophytum stenopetalum.

Chlorophytum Ker-Gawl is a genus in the family Asperagaceace, sub-family Agavoideae of monocotyledonous perennial flowering plant, order Asparagales (Angiosperm Phylogeny Group IV, 2016). This position stated in Angiosperm Phylogenic Group III, 2009 is maintained the new classification (Steven, 2007). The genus comprises about 234 species distributed in tropical and subtropical regions (Gudadhe, Nathar and Dhoran, 2012). Its probable centre of origin and diversification lie in the tropical and sub-tropical Africa and Asia, where $85 \%$ of the species are found (Bordia et al., 1995). A large number of species of Chlorophytum are found on the forest floor in West Africa while several others occur in the guinea savanna regions (Poulsen and Nordal, 2005; Meerts and Bjora, 2012). Chlorophytum stenopetalum is found in the guinea savanna region in Nigeria. The species is a tuberous herb, with rosette of leaves close to the ground. Leaves are linear-lanceolate and leave margin is wavy. Inflorescence is about one fifth as long as leaf, bearing congested fruit. One to three inflorescences grow simultaneously from the centre of the leaves rosette, with the prime inflorescence at the middle. Roots are long bearing tubers at the median position. Though, Chlorophytum stenopetalum is sometimes confused with Chlorophytum macrophyllum, Omokanye et al. (2020), separated the two based on their leaf epidermal morphology, especially stomata index. The genus Chlorophytum is characterized by polyploid evolution having ( $\mathrm{x}=7$ or 8) chromosomes (cf. Baldwin and Speese 1951, Darlington and Wylie 1955, Sharma and Chatterjee 1958, Sharma and Raju 1967). Thus, some of the species belong to 7-basic series while others belong to 8-basic series. Previous cytological works on species of Chlorophytum stenopetalum indicate a diploid chromosome number of 2n=14 (Adeyemi ,1974; Ngwa, 1979 and Omokanye 2016). Meiotic chromosomes behavious in Chlorophytum stenopetalum is investigated with the view of verifying the existing diploid number and also to unravel processes that may hinder normal microspore formation hence affecting pollen fertility.

\section{MATERIALS AND METHODS}

Samples of species of Chlorophytum stenopetalum used for these studies were collected at the onset of the rain in the month of March, 2013, from a village called Shika dam, about $35 \mathrm{~km}$ south of Ahmadu Bello University, Zaria. These materials were raised in pots containing garden soil, in the Department of Plant Biology of University of Ilorin. Most of the plants produced flowers approximately a mouth after vegetative growth has been established, while others produce flowers much later. 
The flower buds at different stages of development were harvested and fixed immediately in freshly prepared Cornoy's solution (3 part of absolute alcohol and 1 part of acetic alcohol) and preserved in a refrigerator at $-4^{\circ} \mathrm{C}$ for at least thirty minutes, to allow for proper fixing of the cells and the removal of mucilage from the anther. The flower buds were then hydrolyzed in $10 \% \mathrm{HCl}$ for $3-5$ minutes so as to allow for easy removal of the perianth segments. Anther from hydrolyzed flower bud was squashed on a clean slide on which a drop of acetic orcein stain had been placed. Prepared slides were viewed using an armscope microscope equipped digital automatic camera.

\section{RESULTS AND DISCUSSION}

The meiotic cell division was studied from pachytene/diakinesis to full meiotic metaphase by observing microsporocytes. A total of 863 microsporocytes were studied. In diakinesis, the pollen mother cells (PMCs) revealed $n=7$ (bivalents) for the taxa. These results thus complement the mitotic results reported earlier. Apart from the bivalents, the taxon presented different chromosomal associations, with varying frequencies of quadrivalent and hexavalents as shown in each of the plates 3. Table 1 shows frequency of occurrence of the pairing patterns in C. stenopetalum.

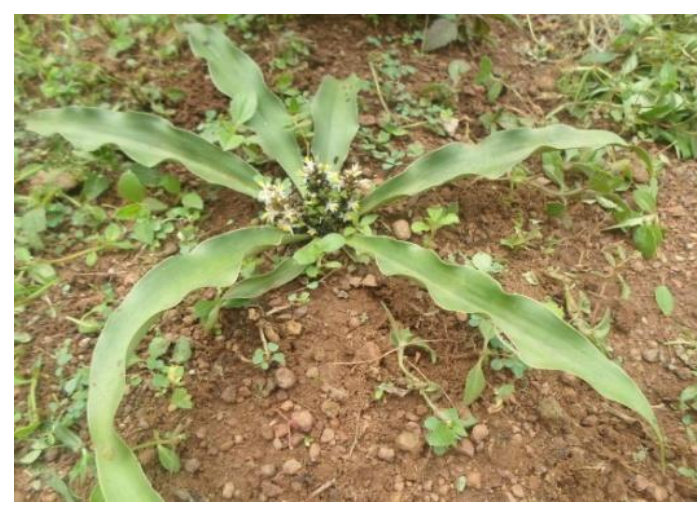

Plate 1. Chlorophytum stenopetalum at maturity stage

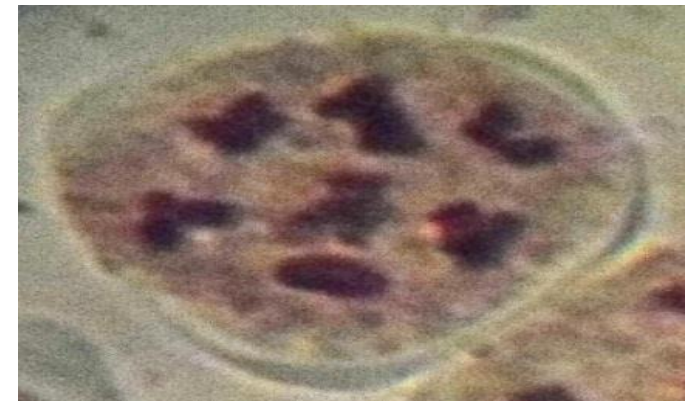

Plate 2. Chromosome association (pairing) in metaphase I in the C,stenopetallum, showing diakinesis with seven bivalents (7 II).
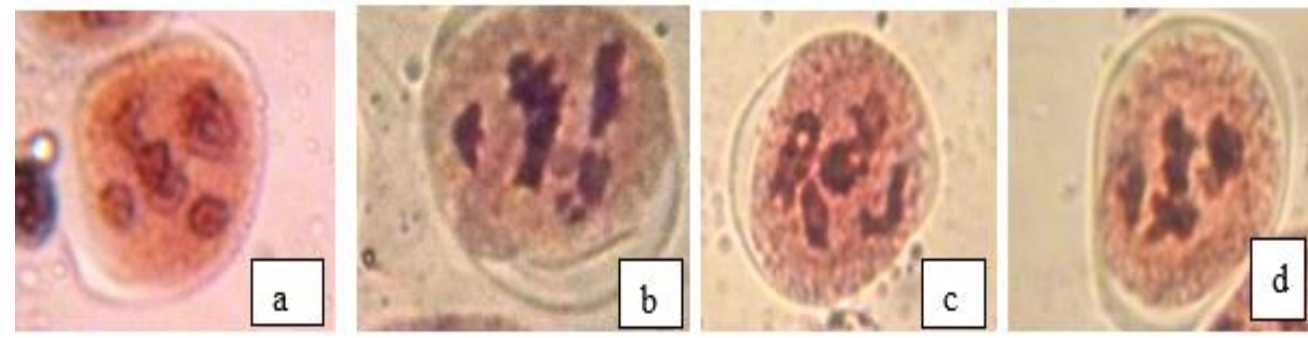

Plate 3a-d): Chromosome association (pairing) in metaphase I in the taxon. a) Metaphase with 1IV+5II. b) Metaphase showing 2IV+3II c) Metaphase with 1VI+4II. d) Metaphase with 3IV+1II. Other meiotic irregularities observed include; chromosome clumping on the spindle fibers, cross shaped configuration at the pachytene stage of meiosis and twisted ring and open ring configuration at meiotic metaphase.

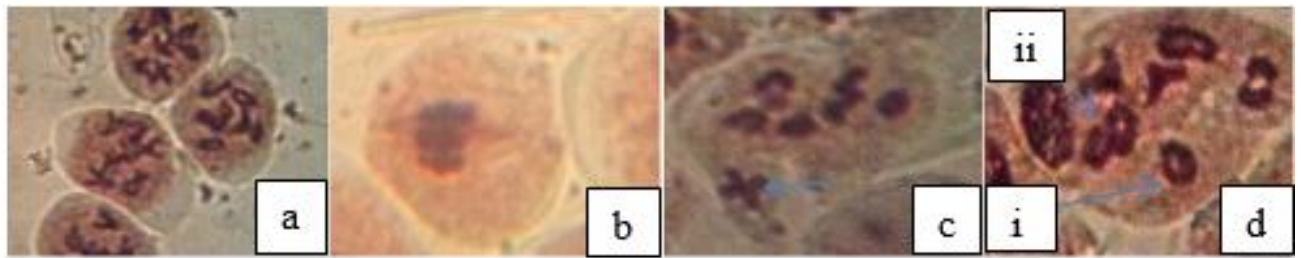

Plate 4; Meiotic irregularities: a, Chromosome pairing at pachytene stage b, first meiotic metaphase with spindle apparatus and chromosome clumping c, Cross shaped configuration at pachytene, di, Open ring configuration at meiotic metaphase ii, Twisted ring configuration at meiotic metaphase

Table 1. Chromosome pairing configurations (\%) at diakinesis in Chlorophytum stenopetalum $(\mathrm{I}=$ univalents; $\mathrm{II}=$ bivalents; IV = tetravalents)

\begin{tabular}{llllll} 
Taxon & $\begin{array}{l}\text { Chromosome } \\
\text { number }\end{array}$ & Pairing & $\begin{array}{l}\text { Configurations } \\
(\%)\end{array}$ & \\
\hline $2 \mathrm{n}=14$ & 7II & 5II+1IV & 4II+1VI & 3II+2IV & 1II+3IV \\
\hline
\end{tabular}




\begin{tabular}{llllll} 
C.stenopetalum & 74.2 & 12.8 & 8.3 & 3.3 & 1.4 \\
\hline
\end{tabular}

Table 2. Chromosome behavior at pachytene/diakinesis and metaphase I in Chlorophytum stenopetalum. Percentage (\%) of observed configurations

\begin{tabular}{lllll}
\hline Taxon & \multicolumn{5}{l}{ Observed formations at each of the stages } & & \\
\hline & Cross configuration & $\%$ of PMC with & $\%$ of PMC & $\%$ Chromosome \\
& at pachytene & twisted ring & with open ring & clumping \\
C.stenopetalum & 25.3 & 12.1 & 21.3 & 40.4 \\
\hline
\end{tabular}

The present study constitutes the first report on meiotic chromosome abnormalities and behaviour in Chlorophytum stenopetalum which revealed a high incidence of translocation heterozygosis with a remarkable variety of meiotic chromosome behaviour of a wild population of the genus Chlorophytum in Nigeria. During the meiotic analysis seven bivalents were observed at diakinesis confirming that the species exhibits $2 \mathrm{n}=14$ chromosomes. This number $(2 n=14)$ is in accordance with the previous reports for the species (Adeyemi, 1981; Ngwa, 1979 and Omokanye, 2016). The present work thus indicates C.stenopetalum belongs to $\mathrm{x}=7$ series of the genus. Though most of the pollen mother cells at diakinesis had regular meiotic behaviour showing seven bivalents (74.2\%), some of the homologous chromosomes paired up forming multivalent. In most cases, chromosomes intermesh losing their individual structure, forming a compact mass on the spindle fiber (Plate 4b), an abnormally generally referred to as chromosomal stickiness. Chromosome stickiness constitutes the highest frequency (40.4\%) of abnormality observed at metaphase I. According to Pagliarini et al.(1993) and Muniyamma and Kameshwari (1996) the meiotic abnormalities such as tetravalents, precocious movement of chromosome, lagging chromosomes and chromatin bridges are found frequently in most of the species of Chlorophytum. Chromosome stickiness is caused due to genetic and environmental factors and several agents have been reported to cause chromosome stickiness (Pagliarini, 2000). Gaulden (1987), reported that stickiness may result from defective functioning of one or more types of specific non histone protein involved in chromosome organization, which are needed for chromosome separation and segregation. The altered functioning of these proteins is caused by mutation in the structural genes coding for them (hereditary stickiness) or by the direct action of mutagens (induced stickiness). Olorode (1972) however, attributed meiotic irregularity such as multivalents, univalents laggard and non-disjunction in some Nigerian plants to structural heterozygosity or Polyploidization. Evidence of translocation heterozygosity is easily detectable as cross configurations which are observed at the pachytene stage (plate 4c). This can result from segmental translocation. At metaphase, the translocation heterozygotes have problem in pairing up hence the formation of open ring configuration at meiotic metaphase (Plate 4di) and twisted ring configuration at meiotic metaphase (Plate 4dii). However, the percentage of cross configuration observed $(25.3 \%)$ is outstretched by the sum of total of twisted and open ring formation (33.4\%), the presence of the two configurations in reasonable number establish the presence of translocation heterozygosity in the species. The spartial orientation of meiotic chromosomes of translocation heterozygotes in relation to the poles of the cell division influences the proper distribution of chromosome complements into daughter nuclei during meiosis I, and subsequent viability of spore formed by meiosis (Oyewole, 1987). The haploid number $(n=7)$ reported in this work for Chlorophytum stenopetalum indicates that the species belongs to $n=7$ series in the genus, thus confirming the existing diploid number $(2 n=14)$ reported for the species. Also, meiotic irregularities concerning chromosomes pairing (at metaphase I) is established. These anomalies may affect normal microspore formation, thereby reducing pollen viability and fertility of the species.

\section{REFERENCES}

Adeyemi FA. (1981). Biosystematic studies in some Nigerian species of Anthericum Linn. and Chlorophytum Ker-Gawl (Unpublished Ph.D. Thesis) University of Ibadan. Ibadan.

Angoisperm Phylogeny Group III (2009). An update of the angiosperm phylogeny group classification for the orders and families of flowering plants. APG III. Botanical J. Linnean Soc. 161(2): $105-121$.

Angiosperm Phylogeny Group IV (2016). An update of the Angiosperm Phylogeny Group classification for the orders and families of flowering plants: APG IV. Bot. J. Linnean Soc. 181: 1-20.

Baldwin JT, Speece BM (1951). Cytogeography of Chlorophytum in Liberia. American Journal of Botany, 38(2): 153-15 
Bordia PC, Joshi A. Simlot MM (1995). Safed musli In Medicinal and Aromatic Plants, (Eds, K.L. Chadha and R. Gupta). Advances in Horticulture, Malhotra Publishing House. New Delhi, pp. $429-451$.

Darlington CD, Wylie AP (1955). Chromosome Atlas (2nd Ed.). George Allen and Unwin Ltd., London.

Gaulden ME (1987). Hypothesis: some mutagenes directly alterspecific chromosomal proteins (DNA) topoisomerase II and peripheral proteins) to produce chromosome stickiness, which causes chromosome aberrations. Mutagenesis, 2: 337 365.

Gudadhe SP, Nathar VN, Dhoran VS (2012). Meiotic Abnormalities in Chloirophytum comosum (Thunb) Jacq. International journal of research in plant science, Universal research publication. 2(2): 29-34.

Meerts, P. and Bjora, C. S. (2012). Synopsis of the genus Chlorophytum (Asaragaceae) in Central Africa (Democratic Republic of the Congo, Rwanda, Burundi). Pl. Ecol. 145:(373-409).

Muniyamma M, Shiva Kameshwari MN (1996). Cytological studies in Chlorophytum elatum. (Liliaceae): Mysore Univ. 34: 1-4.

Ngwa FC (1979). Cytogenetic studies in Nine taxa of the genus Chlorohytum Ker-Gawl. in Nigeria (Unpublished Ph.D. Thesis), University of Ibadan, Ibadan.

Olorode O (1972). Cytogenetical studies on some Nigerian Androgoneae. Nigeria J. Sci. 6: 1319.

Omokanye SB (2020). Chlorophytum sabiense (Asperagaceae) A new species from Nigeria. $J$. Appl. Sci. Environ. Manage. 24(11) 1967- 1968

Omokanye SB, Mustapha OT, Abdulrahamanm AA, Kolawole SO (2020). Leaf Epidermal Studies of fur Species of Chloropytum in Nigeria. J. Appl. Sci. Environ. Manage. 24(11) 1967- 1968.
Omokanye SB (2016). Biosystematic studies of the genus Chlorophytum Ker- gawl.in the rain forest and savanna vegetation zones of Nigeria (Unpublished Ph.D. Thesis) University of Ilorin, Ilorin.

Oyewole SO (1987). Cytotaxonomic studies in the genus Urginea Stein. In West Africa. III. The case of Urginea indica (Roxb.) Kunth in Nigeria. Annals of the Missouri Botanical Garden.,74

(1): 131-136.

Pagliarini MS, Pissinatti MB, Silva N (1993). Chromosomal behaviour and seed production in Chlorophytum comosum (Liliaceae). Cytologia, 58: 433-437.

Pagliarini MS (2000). Meiotic behavior of economically important plant species: the relationship between fertility and male sterility. Genet. Mol. Biol. 23: 997-1002.

Poulsen AD, Nordal I (2005). A phenetic analysis and revision of Guineo-Congolian rain forest taxa of Chlorophytum (Anthericaceae). Bot. J. Linnean Soc. 148: 1-20.

Sharma AK, Chatterji AK (1958). Chromosome studies as a means of detecting the method of speciation in some members of Liliaceae. Genet. Iber., 10: 149-178.

Sharma AK, Raju DT (1967). Cytological analysis of six species of Chlorophytum. Bull. Bot. Soc.,Bengal 21 (1): 37-46.

Stevens PF (2001 onwards). Angiosperm Phylogeny Website. Version 14, July2017 [09/10/2020].http://www.mobot.org/MOBOT/res earch/APweb/. 